\title{
Women's Political Deprivation: A Natural Selection or Cultural Injustice The Case of Pakhtun Society, Pakistan
}

\author{
M. Israr (Muhammad Israr)ㄱ, A. Naz (Arab Naz)2, A. Gul (Ayesha Gul)³, F. Khan \\ (Faisal Khan)4 ${ }^{4}$ W. Khan (Waseem Khan) ${ }^{5}$
}

${ }^{1}$ Assistant Professor, Department of Sociology, Shaheed Benazir Bhutto

Original Article University Sheringal, Dir Upper

${ }^{2}$ Professor Department of Sociology, University of Malakand, Chakdara, Dir Lower

${ }^{3}$ Department of Social Work, SBKWU University Baluchistan, Pakistan

${ }^{4}$ Assistant Professor Management Sciences University of Sawabi, Pakistan

${ }^{5}$ Lecturer Sociology University of Malakand Pakistan

\section{E-mail address:}

arab_naz@yahoo.com

\section{Reprint address:}

Arab Naz

University of Malakand

Chakdara Khyber Pakhtunkhwa

Pakistan

Source: Clinical Social Work and Health Intervention

Pages: $44-58$
Volume: 9

Issue: 4

Cited references: 52

\section{Reviewers:}

Pawel Czarnecki

Rector of the Warsaw Management University, Poland

Selvaraj Subramanian

SAAaRMM, Kuala Lumpur, Malaysia

\section{Key words:}

Participation, Politics, Social Structure, Patriarchy, Decision Making, Pakhtun. Culture.

\section{Publisher:}

International Society of Applied Preventive Medicine i-gap

CSWHI 2018; 9(4): 44 - 58; DOI 10.22359/cswhi_9_4_07 (C) 2018 Clinical Social Work and Health Intervention 


\section{Abstract:}

Politics is considered men's business; the people with riches and plenty of time. However, it is more vital for the vulnerable segments of Society, to commit them in changing the environment that affects their lives. The current study was conducted concerning cultural barriers toward women's political participation in Pakhtun Society, collecting the data from a sample of 320 women councilors using a questionnaire/ interview schedule. SPSS 20, was used for univariate and bivariate analysis, applying chi-square test for possible association. This study revealed that social structure has a phenomenal role in women's least participation in politics in Pakhtun Society. Inferences of the statistics discovered that the main cultural hindrances to women's political participation include: lack of power and authority; stereotypical image; heavy domestic burdens; strong patriarchy; lack of women's choices; women's association with family honor.

On the basis of the findings, this study recommends the role of civil Society in highlighting the significance of women's participation in politics. Similarly, the role of mass media and timely implementation of government policies are highly significant in this regard.

\section{Introduction}

Constituting almost half of the total world's population, women are claimed to be not dealt equally with men in many respects including politics (Aslam 2002). Due to gender rights movements and widespread awareness the developed countries portray a better position in context of women's rights (Ibrahim 2005). However, poor developmental indicators can be observed in emerging countries which show vast gender gaps (Omvedt 2005). The Inter-Par-liamentary Union (IPU) (2017) revealed that the global female political participation ratio is $22.5 \%$ indicating a lack of female representation in the political process due to the hold of traditionalism and socio-economic factors. Kazmi \& Quran (2005) believed that two reasons behind low participation are women's illiteracy and socio-economic hurdles.

Omar (2015) argued that women's political empowerment is a precondition for socio- economic, political development and social security. Studies reveal that women's disem-powerment is caused by inflexible socio-cultural environments sponsored by religious manipulation, patriarchy and economic dependency (Naz 2011). Similarly, misunderstood folk wisdom and cultural norms have considered women a delicate gender who cannot shoulder political responsibilities even in the majority of societies (Khan 2011). Similarly, sidelining women from political responsibilities is due to normative structure; economic dependency; religious misinterpretation (Shaheed, 2009). In most countries, women have been given nominal representation in political institutions, governance and decision making bodies (Kittilson 2006). Roza, (2010) believed that the role of political parties is not supportive to women's participation because they are framed by male dominated social setup and institutions.

Studies have indicated that women are deprived of political participation and governance in most societies due to their biological make-up and illiterate status (Bari 
2009). As claimed by Ali \& Akhtar (2012), the reason behind these deprivations are cultural norms, traditions and conventional folk arrangements perpetuating these theories across generations. Similarly, UNDP (2005) explores that due to such continuous negligence in political affairs women have least understanding of political processes. Research suggests that democratic values can be streng-thened when there is maximum participation of both genders in main stream activities (Stein 1997). Contrarily, in most of societies due to structural barriers, women are discouraged from participating in decision making, casting votes or contesting in elections (Bose \& Rossi 1983).

Based on hypothetical understanding of biological differences in majority of societies, the household is considered the women's world; public activities are men's realm (Prince 2005). Naturally equipped for procreation and nourishment, women are considered fit for such domestic responsibilities whereas men's ability to leave their children for long periods are more likely to become engaged in outside activities e.g. hunting and fighting (Rustagi 2000). However, the advent of household technology has made things easier and able to be managed without any concern for muscular power.

Since their childhood, women in the developing world have low status, fewer rights, less opportunities and rare benefits that have lifelong effects (Rizvi, 1980). Female children are taught at a very early age to accept blame; anger; abuse; any other limitations within the family. Similarly, discrimination in food, dress, education, health care, marriage choice and inheritance is common in majority of the Cultures including Pakhtun Culture (Population Census 1991). Adams (1997) remarked that girls are married young at age 15 or less, due to their temporary status at their father's home. This young age again has negative impact upon gender relations in the marriage union; marital relations; perpetuates low status in relation to men (Prince 2005).

Devlin \& Elgie (2008), believed that due to historical dominancy of patriarchy in societies all institutions are male dominated where men outnumber women and hence their representation is affected on all platforms. In some parts of Palistan, especially Pakhtun Society, women are still prevented from casting their vote (Aziz \& Abdullah 2012). Research studies show the majority of contemporary societies are latently or manifestly patriarchal (Lockard, 2007), a social system where men dominate primary roles in social; political; economic; religious spheres (Malti-Douglas 2007). A study conducted by Aalberg \& Jenssen (2007) explains that traditionally men are considered more gifted and prudent than women. Similarly, male politicians are expected to be more intelligent, trustworthy, popular and convincing. Similarly, Popkin (1991) believed that women are commonly considered more conventional and traditionalistic than men. In fact, voters use known beliefs to support a particular gender according to the prevailing public opinion (Thomas 1997). However, the role of public offices and political institutions is of prime import to address gender biasness; distribution of powers; recognition of gender equality in Culture; knowledge; production; opinion building (Skalli 2011). From given discussion, it is evident that in many societies women are negatively portrayed affecting public and political participation.

\section{Study Argument}

As in numerous societies of the world, Pakhtun family structure is basically patriarchal in nature. This leads to several structural and functional restraints in Society to hinder women from partici-pation in public at individual (education, jobs, business) and collective levels (party, meetings, 
entrepreneurship and groups), as well. However, these structural and functional limitations need to be changed at both levels: individual and collective for the betterment of Society (Bari 2005). The target area of this study is traditional Pakhtun Society which has been managed under the conventional and customary law commonly known as Pakhtunwali (Pakhtun codes of conduct) (Naz 2011, Khan 2011). In Pakhtun Society, gender has been the major source of: division of labor; socio-cultural roles; religious; economic; political opportunities. In this context gender is sidelined in politics and empowerment due to sex segregation. Reasons behind this abstention are: low literacy; no roll in decision making processes; patriarchy; religious misconception; economic dependency; male dominancy (Ali, Fani, Afzal, \& Yasin 2010).

Development is a holistic approach where all segments of Society act collectively to participate in socio-economic and political uplifting (Saleem 2010). Researchers, like Banting in her study (2003) in Afghanistan, concluded that Pakhtunwali ( $\mathrm{Pa}$ khtun code of conduct and Pakhtun way of life) consider women as their honor and protect her from physical or vocal harm. Thus, she is prevented from public exposure and is strictly limited to home. This marginalization compels women to live under the culturally defined rules of Pakhtunwali: centuries old customs; socio-cultural constraints; blatant misappropriation of religion (Banting 2003). The situation is further aggravated by the reluctance of affirmative action to mitigate exploitation of women or encourage empowerment of women (Reyes 2002).

Similarly, Aslam (2002) opined that under representation of women in political spheres is due to the masculine hold over the power and economic resources which is the running wheel of all their worldly affairs. Likewise, all social and formal institutions are masculine and the socialization process of the study area reinforce patriarchy and male dominance (Basu 2005). Nevertheless, cultural and social values and misinterpreted folk wisdom explain women as a delicate sex who could not shoulder political burdens. Thus in third world countries including Pakistan, political affairs are mostly explained by male dominated religious, social, cultural environments and hence inclusion of women in politics is restricted (Khan 2011).

In addition, lack of financial resources hampers the decision making powers of women in family and community. At the most physical level, bearing and rearing children are considered to be the main hindrance to women's entry into the public domain (Aderinwale 1997). Most importantly this segregation has been justified by the misuse of religion. For example, the Purdah system (veil) has been considered an impediment to the simple act of casting a vote or their candidature (Shaheed 2009). Rural areas, especially PATA and FATA, portray a worse picture where codes of life are traditional and thus assign more powers to men in the hierarchy of Society (Noreen \& Musarrat 2013). The major source of stratification in Pakhtun Society is gender which in many cases lead to gender discrimination female subordination; little economic freedom (Ali et al. 2010). It has been further elaborated that women have been allotted secondary status that deprive them from political and economic affairs (Naz 2011, Khan, 2011).

The institutional dominance of men and socialization processes further reinforce male dominancy (Basu 2005). Similarly, lack of infrastructure; unavailability of educational facilities; social conduct; poverty; general perceptions are against female education (Sheikh, 2009). This is why in some parts of the country, especially Pakhtun Society, women are still prevented from casting votes (Aziz \& Abdullah, 2012). It is 
therefore summarized that the base of all the discri-mination against women is the normative structure which define the statuses of genders and allocate roles in the Society. However, the advent of modern technology has filled the gap for requirement of physical power to do public activities. Similarly, least presence of women in educational, economic and religious institutions affect women's political participation.

\section{Materials \& Methods}

The current study is framed under a quantitative approach where the data was analyzed through the Statistical Package decrease sampling error, propor-tional representation technique was adopted, as given in Table-1 below which shows the total number of women representatives in Malakand Division is 1,871 local government councilors.

A sample of 320 was selected according to Sekaran \& Bougie (2016) Table for sample selection for the given sample frame. Hypotheses of the study are as under:

$\mathrm{H}_{0}$ : Pakhtun social structure has no association with women's participation in politics.

H1: Pakhtun social structure has significant association with women's participation in politics.

Table 1: District wise proportional allocation of the sample

\begin{tabular}{|c|c|c|}
\hline District & $\begin{array}{c}\text { Stratum } \\
\text { Population }\end{array}$ & $\begin{array}{c}\text { Stratum } \\
\text { Sample }\end{array}$ \\
\hline Chitral & 217 & 38 \\
\hline Dir Upper & 263 & 44 \\
\hline Dir Lower & 421 & 73 \\
\hline Swat & 328 & 56 \\
\hline Shangla & 230 & 39 \\
\hline Buner & 228 & 38 \\
\hline Malakand & 184 & 32 \\
\hline Grand Total & 1,871 & 320 \\
\hline
\end{tabular}

Sample Frame: 1,871 Sample size: 320

Formula: Population of Stratum x Sample Size

Total Population

for Social Sciences (SPSS) 20. Univariate analysis was conducted for frequencies and percentages. To test possible association between variables, bivariate analysis was conducted through chi-square test at 0.05 level of significance. The universe of this study remained 7 districts of Malakand Division, Khyber Pakhtunkhwa, Pakistan. A sample of 320 women councilors in the district council, tehsil council, union council and village council were interviewed through questionnaire and interview schedules. To

\section{Univariate Analysis}

Univariate analysis in this study is composed of frequencies and percentage Tables. The results in this chapter have been discussed under three sections. Section I reveals discussion on 'Demographic Profile'; Section II 'Pakhtun Social Structure'; Section III 'Women's political participation'. Detailed discussion is given below. 


\section{Section I: Demographic Profile}

This section is an important indicator toward the social, economic and psychological representation of the respondents and their thinking preferences. In the study the demographic profile is composed of: age wise distribution; literacy ratio; marital status; professional status. The following Table 2 guides us further in the mentioned regard: Table 2 displays age wise distribution of the sample respondents. It is apparent from the data that out of $320(100 \%)$ respondents, $118(36.9 \%)$ were in the range of ages 25 35 years; $152(47.5 \%)$ were ages 36-45 years; while $50(15.6 \%)$ were ages 46 years and above. The Table showed that majority of the respondents were in the age group 36-45 years which is a group of mature and well experienced people. The second major age group 25-35 indicates that a majority of the respondents are educated youth serving as representative in the local government. Similarly, among the total 320 (100\%); 234 $(73.1 \%)$ a significant majority is married. It has been noted that married women are more trusted to take part in the activities outside home especially in politics (Lieb \& Thistle 2005). Similarly, 73 (22.8\%) are single while, a minimum number 13 (4.1\%) are separated as divorced or widowed.

Table 2: Age, Marital Status, Educational Status, Family Type, Occupation of Respondents

\begin{tabular}{|l|l|l|}
\hline Statement & Frequency & Percentage \\
\hline Age of the respondents \\
\hline $25-35$ & 118 & 36.9 \\
$36-45$ & 152 & 47.5 \\
Above 46 & 50 & 15.6 \\
Total & 320 & 100 \\
\hline Marital status of the respondents \\
\hline Married & 234 & 73.1 \\
\hline Single & 73 & 22.8 \\
\hline Separated & 13 & 4.1 \\
\hline Total & 320 & 100 \\
\hline
\end{tabular}

\begin{tabular}{|l|l|l|}
\hline \multicolumn{3}{|l|}{ Educational status of the respondents } \\
\hline Illiterate & 119 & 37.2 \\
\hline Metric & 121 & 37.8 \\
\hline Bachelor & 55 & 17.2 \\
\hline Master & 25 & 7.8 \\
\hline Total & 320 & 100 \\
\hline Family type of the respondent \\
\hline Nuclear & 102 & 31.9 \\
\hline Joint & 201 & 62.8 \\
\hline Extended & 17 & 5.3 \\
\hline Total & 320 & 100 \\
\hline Occupation of the respondent \\
\hline Housewife & 252 & 78.8 \\
\hline Own business & 44 & 13.8 \\
\hline Employee & 24 & 7.5 \\
\hline Total & 320 & 100 \\
\hline
\end{tabular}

Table 2 further illustrates literacy ratio and educational level of the respondents. Out of the total $320(100 \%), 119(37.2 \%)$ were illiterate; 121 (37.8\%) were matriculate; $55(17.2 \%)$ had bachelor degrees; 25 (7.8\%) were master degree holders. These statistics depict that literacy ratio is not satisfactory among the women involved in the political process. However, these are politically conscious families who are well educated and allow their women to participate in public spheres like education and politics.

The specified Table-2 further shows the family type of the respondent which elucidates that majority $201(62.8 \%)$ are coming from joint family system; 102 (31.9\%) belongs to nuclear family; 17 (5.3\%) belong to anextended family system. Majority of the respondents belong to a joint family system where women have maximum responsibility at home in Pakhtun Society and are prevented from engaging in public activities (Aziz \& Abdullah, 2012).

The Table further explores that a vast majority of the respondents are housewives 252 $(78.8 \%)$; $44(13.8 \%)$ have their own businesses; only $24(7.5 \%)$ are formally employed. 
This shows that women are not allowed to participate in the public sphere. Due to low literacy women in the target area their participation in employment is also quite low.

\section{Section II: Pakhtun Social Structure}

Normative structure or social structure have an important role in social arrangement of institu-tions and norms which are followed by individuals in Society. By social structure we mean the regularities in life which is quite consistent in different societies (Crothers \& Charles, 1996). Social structure is varying according to the context which can take the form of macro (overall system of socio-economic stratification); meso (social network ties between individuals and organization); micro (norms and behavior of an individual in social system)(Merton, 1938).

The following Table-3 will show the structural barriers toward women participation in politics.

Table 3: Pakhtun Social Structure

\begin{tabular}{|l|c|c|}
\hline Statement & Frequency & Percent \\
\hline Least Power with Women in Pakhtun Society \\
\hline Agree & 247 & 77.2 \\
\hline Disagree & 55 & 17.2 \\
\hline Neutral & 18 & 5.6 \\
\hline Total & 320 & 100 \\
\hline $\begin{array}{l}\text { Stereo-typical Image of Women in Pakhtun } \\
\text { Society }\end{array}$ \\
\hline Agree & 250 & 78.1 \\
\hline Disagree & 52 & 16.3 \\
\hline Neutral & 320 & 18 \\
\hline Total & 250 & 78.1 \\
\hline Gender Segregation in Pakhtun Society \\
\hline Agree & 52 & 16.3 \\
\hline Disagree & 18 & 5.6 \\
\hline Neutral & 320 & 100 \\
\hline Total & 49 & 15.3 \\
\hline $\begin{array}{l}\text { Limitation of Women to Homes in Pakhtun } \\
\text { Society }\end{array}$ \\
\hline Agree \\
\hline Disagree
\end{tabular}

\begin{tabular}{|l|c|c|}
\hline Neutral & 13 & 4.1 \\
\hline Total & 320 & 100 \\
\hline Strong Patriarchic system in Family \\
\hline Agree & 258 & 80.6 \\
\hline Disagree & 46 & 14.4 \\
\hline Neutral & 16 & 5.0 \\
\hline Total & 320 & 100 \\
\hline Women are fit for domestic chores only \\
\hline Agree & 248 & 77.5 \\
\hline Disagree & 52 & 16.3 \\
\hline Neutral & 19 & 5.9 \\
\hline Total & 320 & 100 \\
\hline Strict Purdah System (Veil) as a Barrier \\
\hline Agree & 272 & 85.0 \\
\hline Disagree & 37 & 11.6 \\
\hline Neutral & 11 & 3.4 \\
\hline Total & 320 & 100 \\
\hline
\end{tabular}

Women's Participation in Politics is a Threat to Men's Honor

\begin{tabular}{|l|c|c|}
\hline Agree & 246 & 76.9 \\
\hline Disagree & 62 & 19.4 \\
\hline Neutral & 12 & 3.8 \\
\hline Total & 320 & 100 \\
\hline
\end{tabular}

Women's Participation in Politics is a Threat to Pakhtun Traditions

\begin{tabular}{|l|c|c|}
\hline Agree & 273 & 85.3 \\
\hline Disagree & 36 & 11.3 \\
\hline Neutral & 11 & 3.4 \\
\hline Total & 320 & 100 \\
\hline
\end{tabular}

Lack of Freedom to Make a Choice

\begin{tabular}{|l|c|c|}
\hline Agree & 261 & 81.6 \\
\hline Disagree & 45 & 14.1 \\
\hline Neutral & 14 & 4.4 \\
\hline Total & 320 & 100 \\
\hline
\end{tabular}

The above Table-3 demonstrates that out of the total $320(100 \%)$ : a high majority $247(77.2 \%)$ are of the view that Pakhtun social structure hinder women to participate in politics; 55 (17.2\%) disagreed with this statement; while $18(5.6 \%)$ remained neutral. Khan (2011) believes that cultural values and misinterpreted folk wisdom consider women a delicate gender who could 
not shoulder power and political responsibilities.

Table-3 further revealed that $250(78.1 \%)$ agreed that women are stereotyped in Pakhtun Culture; 52 (16.3\%) disagreed; 18 (5.6\%) remained neutral. Aalberg \& Jenssen (2007) explain that men are generally considered more popular, gifted and prudent. Similarly, Popkin (1991) believed that women are commonly considered more conventional because of religious and cultural stereotyping against women (Ibrahim 2005).

Table-3 further displays that out of the total $320(100 \%)$ : a vast majority 250 $(78.1 \%)$ believed that women are segregated from main stream public activities; 52 (16.3\%) disagreed; 18 (5.6\%) were neutral. Sattar (2012) found that segregation of women from main stream public activities is a violation of basic human rights.

Table-3 shows that out of 320 (100\%): $258(80 \%)$ opined that there exists a common notion in Pakhtun Society that 'women are either for home or for grave'; 49 (15.3\%) disagreed; 13 (4.1\%) remained neutral. Basu, Amriyta, Jayal, Naraja Gopal, \& Yasmin (2003) believed that societies with strong patriarchy make it difficult for women to compete in the open arena against powerful men. This way their interests are getting more suppressed than properly addressed.

Table-3 further discloses that out of the total $320(100 \%)$ : a strong majority 258 $(80.6 \%)$ agreed that a strong patriarchic system has been the obstacle in women's political participation; 46 (14.4\%) disagreed; while $16(5.0 \%)$ remained neutral. Aslam (2002) argued that women's under representation in political spheres is due to the masculine hold over power and economic resources. Likewise, social and formal institutions reinforce patriarchy and male dominance (Basu 2005).

Table- 3 revealed that out of the total 320 sample: $248(77.5 \%)$ believed that in $\mathrm{Pa}$ khtun Society women are considered fit for domestic chores only; 52 (16.3\%) disagreed; $19(5.9 \%)$ remained neutral. Researchers have concluded that women in the rural setup face major problems in their due rights because of poverty; lack of access to land; unemployment; illiteracy; heavy domestic workload (International Alert Report 2012).

Table- 3 confirms that out of the total 320 (100\%) respondents: $272(85.0 \%)$ agreed with the statement that women are debarred from politics due to the strict purdah system; 37 (11.6\%) disagreed; 11 (3.4\%) remained neutral. Shaheed (2009) believed that the undue and strict Purdah system (veil) is considered an impediment to the simple act of casting vote and candidature.

Table-3 further explains that out of the total $320(100 \%): 246(76.9 \%)$ agreed that women are not allowed into politics because they are considered a threat to Pakhtun honor (ghairat); 62 (19.4\%) disagreed; $12(3.8 \%)$ remained neutral. In a patriarchal system the normative structure maintains a strict moral and honor code for women while the women have to abide by strict cultural practices to preserve their chastity and not to defame the family (Khan 1999).

Table-3 explains that out of 320 (100\%): $273(85.3 \%)$ are of the view that in Pakhtun Culture women participation in politics is considered a threat to Pakhtun traditions; 36 (11.3\%) disagreed; 11 (3.4\%) remained neutral. Studies reveal that Pakhtun Society has been managed under the conventional and customary law commonly known as Pakhtunwali (Pakhtun codes of conducts) (Naz 2011 Khan, 2011). Gender has been the major source of division of labor; socio-cultural roles; religious; economic; political opportunities in Pakhtun Society. Thus, women are sidelined in the politics and decision making process (Ali et.al 2010).

Table-3 further illustrates that out of the total $320(100 \%)$ : 261 (81.6) were of the view that women are not allowed to make a choice in voting and contesting election 
but to follow the men, 45 (14.1\%) disagreed, $14(4.4 \%)$ remained neutral. Studies explain that, the notion of women empowerment also has a contribution to individual choice of selection (Basu et al. 2003).

Discussion of the given Table-3 revealed that nothing else affect women participation in politics more than the prevailing patriarchic system which would never allow women to get a position of power. Similarly, women are deliberately segregated from main stream activities by the dominant men in the Society especially in Khyber Pakhtunkhwa. In addition, negative stereo-typing of women as least intelligent and unproductive has negatively portrayed the stature of women. Also, women's association with family honor and the Pakhtun codes are among the hard barriers for women to overcome. Even their choice in spouse selection has also been curtailed and parents especially father decision has to be obliged.

\section{Section III: Women's Political Participation}

Women constitute about half of the world population but have traditionally been discriminated in many aspects of life including politics (Aslam 2002). Currently, developed countries are nonetheless in a better position to address gender issues due to women's movements and widespread awareness (Ibrahim 2005). On the contrary, developing countries still experience gender gaps which manifest themselves in poor developmental indicators (Omvedt 2005).

Table 4: Women's Political Participation

\begin{tabular}{|l|l|l|}
\hline Statement & Frequency & Percentage \\
\hline $\begin{array}{l}\text { Pakhtun Social Structure \& Women's Partici- } \\
\text { pation in Politics }\end{array}$ \\
\hline Agree & 270 & 84.4 \\
\hline Disagree & 28 & 8.8 \\
\hline Neutral & 22 & 6.9 \\
\hline Total & 320 & 100 \\
\hline
\end{tabular}

\begin{tabular}{|c|c|c|}
\hline \multicolumn{3}{|c|}{$\begin{array}{l}\text { Women's Economic Dependency \& Political } \\
\text { Participation }\end{array}$} \\
\hline Agree & 265 & 82.8 \\
\hline Disagree & 31 & 9.7 \\
\hline Neutral & 24 & 7.5 \\
\hline Total & 320 & 100 \\
\hline \multicolumn{3}{|c|}{$\begin{array}{l}\text { Mass Illiteracy \& Women's least Interest in } \\
\text { Politics }\end{array}$} \\
\hline Agree & 277 & 86.6 \\
\hline Disagree & 25 & 7.8 \\
\hline Neutral & 18 & 5.6 \\
\hline Total & 320 & 100 \\
\hline \multicolumn{3}{|c|}{$\begin{array}{l}\text { Weak \& Deficient Policies \& Women's Politi- } \\
\text { cal Participation }\end{array}$} \\
\hline Agree & 264 & 82.5 \\
\hline Disagree & 27 & 8.4 \\
\hline Neutral & 29 & 9.1 \\
\hline Total & 320 & 100 \\
\hline \multicolumn{3}{|c|}{$\begin{array}{l}\text { Masculine Interpretation of Religion \& Wo- } \\
\text { men's Deprivation }\end{array}$} \\
\hline Agree & 272 & 85.0 \\
\hline Disagree & 26 & 8.1 \\
\hline Neutral & 22 & 6.9 \\
\hline Total & 320 & 100 \\
\hline \multicolumn{3}{|c|}{$\begin{array}{l}\text { Women's Nominal Representation in Political } \\
\text { Parties }\end{array}$} \\
\hline Agree & 276 & 86.3 \\
\hline Disagree & 27 & 8.4 \\
\hline Neutral & 17 & 5.3 \\
\hline Total & 320 & 100 \\
\hline
\end{tabular}

The above Table- 4 displays that out of the total 320 (100\%): $270(84.4 \%)$ agreed that Pakhtun social structure is not supportive to women's political empowerment; 28 (8.8\%) disagreed; $22(6.9 \%)$ were found neutral. Khan (2011) believes that cultural values and misinterpreted folk wisdom consider women a delicate gender who could not shoulder power and political responsibilities.

Table-4 further ascertains that 265 $(82.8 \%)$ agreed that dependence of women on men economically in Pakhtun Culture sideline women from power and authority; $31(9.7 \%)$ disagreed; $24(7.5 \%)$ remained 
neutral. Welle \& Heilman (2007) believe masculine popular Culture customs; traditions; laws; policy procedures provide little opportunities for women to take a lead. Women thus remain dependent on men economically, in decision making and in politics.

Table-4 further tells us that out of the total $320(100 \%): 277(86.6 \%)$ agreed that mass illiteracy in female leads to least understanding of the political system; 25 (7.8\%) disagreed; 18 (5.6\%) remained neutral. Karl (2001) identifies the main obstacles to women's participation in politics as their low education, illiteracy; lack of access to information; low socialization.

Table-4 explains that out of the total 320 (100\%): $264(82.5 \%)$ agreed that enactment of proper policies for mainstreaming women in politics are deficient; while 27 (8.4\%) disagreed; 29 (9.1\%) remained neutral. Kingdon (1984), observes that lack of rational policies hinder promotion of gender equality in politics. Prudent policies by professionals are more important than any method and technique of empowernent.

Table-4 elucidates that out of the total $320(100 \%): 272(85.0 \%)$ agreed that male dominated religious institutions stop women from participation in public activities including politics; 42 (13.1\%) disagreed: 21 $(6.6 \%)$ remained neutral. It is commonly understood that non-participation of women in politics is obstructed by three distinct but interconnected variables: social structure; economic disadvantages; religious miss interpretation (Shaheed, 2009).
Table- 4 ascertains that out of the total $320(100 \%) ; 276(86.3 \%)$ agreed that women are not included in political parties; 27 (8.4\%) disagreed; 17 (5.3\%) remained neutral. Roza (2010) understand that political parties influence the whole political milieu, yet they too are shaped by the patriarchic system.

It is evident from the above discussion that in addition to structural barriers the economic dependence of women are always at the disposal of men in each and every decision including politics. Similarly, illiteracy not only affects their life at home but also the public sphere of women as well. Besides, timely legislation and implementation in the real sense is important. This way, the rights of the women can be safeguarded and will eventually eradicate all sorts of discrimination against her. The role of political parties to streamline women in politics is of utmost significance.

\section{Bi-Variate Analysis}

Social structure includes every phenomenon in Society from larger system to individual behavior and therefore its role is of prime importance in the behavior and attitude of the individual living in Society. Cross cultural studies reveal that women are disempowered because of the problems ordained in the rigid socio-cultural conditions backed by religious misappropriation; economic dependency; male dominated values (Naz, 2011).

Table 5: Impacts of Pakhtun Social Structure upon Women's Political Participation

\begin{tabular}{|l|l|l|l|l|l|}
\hline $\begin{array}{c}\text { Statements } \\
\text { In Pakhtun social stru- } \\
\text { cture: }\end{array}$ & Response & \multicolumn{3}{|c|}{ Women's Political Participation } & \\
\hline & & \multicolumn{1}{|c|}{ Agree } & Disagree & Neutral & Statistic \\
\hline $\begin{array}{l}\text { Women have no } \\
\text { power/authority which } \\
\text { leads to least participa- } \\
\text { tion in politics }\end{array}$ & Agree & $225(77.9 \%)$ & $22(81.5 \%)$ & $0(0 \%)$ & $\begin{array}{l}=21.284 \\
=0.000\end{array}$ \\
\cline { 2 - 6 } & Disagree & $48(16.6 \%)$ & $5(18.5 \%)$ & $2(50 \%)$ & \\
\cline { 2 - 7 } & Neutral & $16(5.5 \%)$ & $0(0 \%)$ & $2(50 \%)$ & \\
\hline
\end{tabular}




\begin{tabular}{|c|c|c|c|c|c|}
\hline \multirow{3}{*}{$\begin{array}{l}\text { Stereo-typical image } \\
\text { of women is a cause of } \\
\text { least participation in } \\
\text { politics }\end{array}$} & Agree & $228(78.9 \%)$ & $22(81.5 \%)$ & $0(0 \%)$ & $\begin{array}{l}=21.683 \\
=0.000\end{array}$ \\
\hline & Disagree & $45(15.6 \%)$ & $5(18.5 \%)$ & $2(50 \%)$ & \\
\hline & Neutral & $16(5.5 \%)$ & $0(0 \%)$ & $2(50 \%)$ & \\
\hline \multirow{3}{*}{$\begin{array}{l}\text { Gender segregation } \\
\text { from main stream acti- } \\
\text { vities is a cause of least } \\
\text { participation in politics }\end{array}$} & Agree & $225(77.9 \%)$ & $21(77.8 \%)$ & $2(50 \%)$ & $\begin{array}{l}=4.259 \\
=0.372\end{array}$ \\
\hline & Disagree & $51(17.6 \%)$ & $6(22.2 \%)$ & $2(50 \%)$ & \\
\hline & Neutral & $13(4.5 \%)$ & $0(0 \%)$ & $0(0 \%)$ & \\
\hline \multirow{3}{*}{$\begin{array}{l}\text { Women are for home } \\
\text { or grave, a common } \\
\text { notion hinders women } \\
\text { from politics }\end{array}$} & Agree & $228(89.4 \%)$ & $35(70 \%)$ & $\begin{array}{l}13 \\
(86.7 \%)\end{array}$ & $\begin{array}{l}=21.107 \\
=0.000\end{array}$ \\
\hline & Disagree & $20(7.8 \%)$ & $6(12 \%)$ & $1(6.7 \%)$ & \\
\hline & Neutral & $7(2.7 \%)$ & $9(18 \%)$ & $1(6.7 \%)$ & \\
\hline \multirow{3}{*}{$\begin{array}{l}\text { Strong patriarchic } \\
\text { system in family } \\
\text { hinders women from } \\
\text { active role in politics }\end{array}$} & Agree & $226(77.9 \%)$ & $22(81.5 \%)$ & $0(0 \%)$ & $\begin{array}{l}=21.285 \\
=0.000\end{array}$ \\
\hline & Disagree & $47(16.6 \%)$ & $5(18.5 \%)$ & $2(50 \%)$ & \\
\hline & Neutral & $16(5.5 \%)$ & $0(0 \%)$ & $2(50 \%)$ & \\
\hline \multirow{3}{*}{$\begin{array}{l}\text { Women are considered } \\
\text { fit for domestic chores } \\
\text { only, not politics }\end{array}$} & Agree & $224(77.9 \%)$ & $22(81.5 \%)$ & $0(0 \%)$ & $\begin{array}{l}=21.283 \\
=0.000\end{array}$ \\
\hline & Disagree & $49(16.6 \%)$ & $5(18.5 \%)$ & $2(50 \%)$ & \\
\hline & Neutral & $16(5.5 \%)$ & $0(0 \%)$ & $2(50 \%)$ & \\
\hline \multirow{3}{*}{$\begin{array}{l}\text { Strict Purdah in } \\
\text { Pakhtun is a barrier to } \\
\text { women's participation } \\
\text { in politics }\end{array}$} & Agree & $245(84.8 \%)$ & $24(88.9 \%)$ & $3(75 \%)$ & $\begin{array}{l}=3.702 \\
=0.448\end{array}$ \\
\hline & Disagree & $35(12.1 \%)$ & $1(3.7 \%)$ & $1(25 \%)$ & \\
\hline & Neutral & $9(3.1 \%)$ & $2(7.4 \%)$ & $0(0 \%)$ & \\
\hline \multirow{3}{*}{$\begin{array}{l}\text { Women's political par- } \\
\text { ticipation is a threat to } \\
\text { men's honor (Ghairat) } \\
\text { which restrict them }\end{array}$} & Agree & $226(78.2 \%)$ & $19(70.4 \%)$ & $1(25 \%)$ & $\begin{array}{l}=11.201 \\
=0.024\end{array}$ \\
\hline & Disagree & $51(17.6 \%)$ & $8(29.6 \%)$ & $3(75 \%)$ & \\
\hline & Neutral & $12(4.2 \%)$ & $0(0 \%)$ & $0(0 \%)$ & \\
\hline \multirow{3}{*}{$\begin{array}{l}\text { Participation of women } \\
\text { in politics is conside- } \\
\text { red a threat to Pakhtun } \\
\text { traditions }\end{array}$} & Agree & $249(86.2 \%)$ & $21(77.8 \%)$ & $3(75 \%)$ & $\begin{array}{l}=2.532 \\
=0.639\end{array}$ \\
\hline & Disagree & $30(10.4 \%)$ & $5(18.5 \%)$ & $1(25 \%)$ & \\
\hline & Neutral & $10(3.5 \%)$ & $1(3.7 \%)$ & $0(0 \%)$ & \\
\hline \multirow{3}{*}{$\begin{array}{l}\text { Lack of freedom to } \\
\text { choose \& act by her } \\
\text { choice is a cause of } \\
\text { least participation in } \\
\text { politics }\end{array}$} & Agree & $222(87.1 \%)$ & $33(66 \%)$ & $9(60 \%)$ & $\begin{array}{l}=18.395 \\
=0.001\end{array}$ \\
\hline & Disagree & $16(6.3 \%)$ & $8(16 \%)$ & $3(20 \%)$ & \\
\hline & Neutral & $17(6.7 \%)$ & $9(18 \%)$ & $3(20 \%)$ & \\
\hline
\end{tabular}

Table- 5 provides us the bivariate analysis of the first independent variable, Pakhtun Social Structure and its association with the dependent variable of Women's Political Participation.

The chi-square value (21.284) having a highly significant 'p' value (0.000) shows that least power and authority given to women in Pakhtun Culture affect women's participation in politics. Khan (2011) believes that cultural values and misinterpreted folk wisdom consider women a delicate gender who could not shoulder power; political duties; responsibilities. 
Table-5 further provides chi-square value (21.683) having a highly significant ' $p$ ' $(0.000)$ which shows that there is a strong association between the stereotypical image of the women in Pakhtun Society and their political participation. Aalberg \& Jenssen (2007) explain that men are generally considered more gifted; intelligent; trustworthy; convincing than women. Similarly, Popkin (1991) believed that women are commonly considered more conventional and traditional.

The next part of the Table- 5 indicates the chi-square value (4.259) which gives the ' $p$ ' value as $(0.372)$ which is non-significant. The results showed that there is no association between the two variables. Thus gender segregation in mainstream activities is said to have no association with women's political participation.

Similarly, the chi-square value (21.107) having 'p' value as $(0.000)$ is highly significant and hence a strong association between the variables exist. The sample respondents considered that as a common notion woman in Pakhtun Society are considered fit "for home or for grave" as a common maxim. Karl (2001) argued that the main obstacle to women's participation in politics are cultural stereotypes. Similarly, women are considered fit for domestic works only (Ibrahim, 2005).

In the next row the chi square value (21.285) which gives the 'p' value $(0.000)$ is highly significant again and thus signify that in the strong patriarchic system women are not allowed to participate in public activities like politics which is men's job. Societies with strong patriarchy make it difficult for women to compete against the powerful men (UNRISD 2005). Aslam (2002) opined that the under representation of women in the political spheres is due to the masculine hold over the power and economic resources.

Similarly, a chi-square value (21.283) carries ' $p$ ' value $(0.000)$ which is highly significant and hence the association between the two variables exist. It signifies that women in Pakhtun Society are considered fit for domestic chores only. Women are bound to domestic responsibil-ities and the physically strong men who are able to leave their children for a long time are more likely to become engaged in outside activities e.g. hunting and fighting (Rustagi 2000).

Table- 5 further elucidated the chi-square value (3.702) with ' $p$ ' value $(0.448)$ is non-significant and hence the strict purdah system has no significant effect upon women's political participation according to the sampled respondents. However, the Purdah system (veil) has been considered an impediment to the simple act of casting a vote and their candidature (Shaheed, 2009).

The next part of Table-5 explains the chi-square value as (11.201) with ' $p$ ' value as $(0.024)$ which is significant and hence a relation between ghairat (men's honor) and women's political participation exists. The Pakhtun normative structure maintains strict moral and honor code for women to preserve her chastity and not to dehonor males of the family (Khan, 1999).

The next row of the Table- 5 gives Chisquare value (2.532) with 'p' value (0.639) which is again non-significant and hence there is no association between the variables. Thus, women's participation in politics is not considered a threat to Pakhtun traditions.

Table-5 further reveals the chi-square value (18.395) with 'p' value (0.001) which is highly significant. The value explains that women are not free to make their choices which is strongly affecting women's participation in politics. The results are verified by studies which explain that the notion of women's empowerment also has a contribution to individual choice of selection what one considers valuable (Basu et al 2003).

The above interpretation revealed that out of ten statements in independent variable 'Pakhtun Social Structure', only 3 are 
non-significant and 7 variables are highly significant which shows significant association between variables. Thus, the null hypothesis $\mathrm{H}_{0}$ is rejected and $\mathrm{H} 1$ is accepted. To sum up the whole discussion it is decided that Pakhtun social structure significantly affects women's participation in politics.

\section{Conclusions}

This study attempted to probe constraints to women's participation in politics in Pakhtun Society through assuming independent variable; socio-cultural hurdles to women's political participation. The study findings revealed that the social structure of the Society engender the individual since childhood where girls are trained for domestic chores which include caring, washing, cooking. Similarly, girls are considered emotional; less intelligent; least productive. This attitude leads toward her secondary status and over dependence upon men in food; maintenance; health; mobility; politics. However, women's least participation in politics negatively affect the deve-lopment of women and children. It is interesting to add here that modern democratic states are welfare oriented and thus women's virtues are more suited for socio-economic development; education; health; art; literature; mother and child care.

\section{References}

1. AALBERG T, JENSSEN, AT (2007) Gender Stereotyping of Political Candidates an Experimental Study of Political Communication. Nordicom Review, 28 TORIL.1, pp. 17-32.

2. ADERINWALE A (Ed.) (1997). Empowering Women for the 21st Century: The Challenges of Politics, Business, Development and Leadership. Africa Leadership Forum.

3. ALI AA, AKHTAR MJ (2012) Empowerment and political mobilization of women in Pakistan: A descriptive discourse of perspectives. Pakistan Journal of Social Sciences, 32(1), 221-228.

4. ALI W, FANI, MI, AFZAL S, YASIN G (2010). Cultural barriers in women empowerment: a sociological analysis of Multan, Pakistan. European Journal of Social Sciences, 18(1), 147-155.

5. ASLAM T (2002) Women not at War with Men under Feminist Drive. Jang Group of newspaper, Pakistan dated: Jan, 22.

6. AZIZ N, ABDULlAH T (2012) Suggestions on Women's Empowerment for Election Manifestos of Political Parties. Islamabad: Aurat Foundation.

7. BANO S (2009) Women in parliament in Pakistan: Problems \& potential solutions. Women's Studies Journal, 23(1), 19.

8. BANTING E (2003) Afghanistan: The People. Crabtree Publishing Company.

9. BARI F (2005) Women's political participation: Issues and challenges. Division of Advancement of Women (DAW) Expert group meeting, Enhancing participation of women in development through enabling environment for achieving gender equality and advancement of women. Bangkok, Thailand. 8-11 Nov. 2005.

10. BARI F (2009) Role and Performance: Assessment of Pakistan Women Parliamentarians, 2002-2007. Pattan Development Organization.

11. BASU A (2005) Women, political parties and social movements in South Asia (No. 5). UNRISD Occasional Paper. http://www. eldis.ids.ac.uk/static/DOC18454.htm.

12. BASU, AMRIYTA, JAYAL, NARAJA GOPAL, YASMIN (2003) Essays on Gender and Governance. India: Human Development Resource Center, United Nations Development Programme.

13. BOSE CE, ROSSI PH (1983) Gender and jobs: Prestige standings of occupations as affected by gender. American sociological review, 316-330.

14. CROTHERS, CHARLES (1996) Social Structure. London: Routledge 
15. DEVLIN C, ELGIE R (2008) The effect of increased women's representation in parliament: The case of Rwanda. Parliamentary Affairs, 61(2), 237-254.

16. IBRAHIM F (2005) Honor Killings under the Rule of Law in Pakistan. Master of Laws Thesis. Montreal: McGill University.

17. IBRAHIM (2005) Socio-Cultural and Economic Constraints to Women's Political Empowerment in Pakhtun Society. Unpublished M. Phil Thesis. Department of Sociology University of Malakand.

18. INTER-PARLIAMENTARY UNion, (2017). Women in national parliaments, as of 1 June 2017.

19. INTERNATIONAL ALERT REPORT (2012) Women's political participation and economic empowerment in post-conflict countries. Lessons from the Great Lakes region in Africa.

20. KARL M (2001) Women and empowerment: participation and decision making. London: Zed Books Ltd.

21. KAZMI SW, QURAN H (2005) Role of education in globalization: A case for $\mathrm{Pa}$ kistan. SAARC journal of human resource development, 1(1), 90-107.

22. KHAN A (1999) Mobility of women and access to health and family planning services in Pakistan. 7(14), 39-48.

23. KHAN W (2011) The Role of Pakhtun Social Organization in Gendered Decision-Making (A Case study of Batkhela, District Malakand). M. Phil Dissertation. Department of Sociology, University of Malakand.

24. KINGDON JW, THURBER JA (1984) Agendas, alternatives, and public policies (Vol. 45, pp. 165-169). Boston: Little, Brown.

25. KITTILSON MC (2002). Challenging the organization, changing the rules: Women, parties, and change in Western Europe, 1975 to 1997. Unpublished doctoral dissertation. University of California, Irvine.

26. LIEB H, THISTLE S (2005. MARRIAGE, WORK, POVERTY, AND CHIL$D R E N$. Women, Work, and Poverty:
Women Centered Research for Policy Change, 27(3/4), 5.

27. LOCKARD C (2007) Societies, Networks, and Transitions: Volume I: A Global Histo$r y$ (Vol. 2). Cengage Learning.

28. MALTI-DOUGLAS F (2007) Encyclopedia of Sex and Gender. Detroit: Macmillan. ISBN 0-02-865960.

29. MERTON RK (1938) Social structure and anomie. American sociological review, 3(5), 672-682.

30. NAZ A (2011) Socio-Cultural and Political Constraints to Gender Development. An Unpublished PhD Dissertation. Department of Anthropology, Quaid-i-Azam University, Islamabad, Pakistan.

31. NOREEN N, MUSARRAT R (2013) Protection of women rights through legal reforms in Pakistan. Journal of Public Administration and Governance, 3(4), 119-142.

32. OMAR S (2011) Women's Right to Inheritance: Shariah and Pakistan's Law, http:// www.slideshare.net/shaguftaomar/womens-right-to-inheritance-shariah-and-pakistans-laws.

33. OMVEDT G (2005) Women in Governance in South Asia. Economic \& Political Weekly, 40(44/45), 4746-4752.

34. POPKIN SL (1994) The reasoning voter: Communication and persuasion in presidential campaigns. University of Chicago Press.

35. POPULATION CENSUS GOVT. OF PAKISTAN (1990-1991) Manpower and social welfare, 399.

36. PRINCE V (2005) Sex vs. Gender. International Journal of Transgenderism, 8(4), 29-32.

37. REYES SL (2002 September) Quotas in Pakistan: A case study. In International IDEA Workshop "The Implementation of Quotas: Asian Experiences," Jakarta, Indonesia, September (Vol. 25).

38. RIZVI F (1980) Background of vocational education for girls. The national conference on critical issues concerning women in education, March 29-April 03, 1980, Women Div. Govt. of Pakistan, Islamabad. 
39. ROZA V (2010) Gatekeepers to power: Party-level influences on women's political participation in Latin America. Ph.D. Dissertations. Georgetown University, 237; 3433183.

40. RUSTAGI P (2000) Identifying gender backward districts using selected indicators. Economic and Political Weekly, 42764286.

41. SALEEM W (2010) State of Women in Pakistan. Weekly Report. Daily the News. 22 January, 2010.

42. SATTAR S (2012) Opportunities for men and women: Emerging Europe and Central Asia. Washington, DC: World Bank.

43. SEKARAN U, BOUGIE R (2016) Research methods for business: A skill building approach. John Wiley \& Sons.

44. SHAHEED A (2009) Women in Politics: Participation and Representation in Pakistan, An overview. Shirkat Gah- Women's Resource Centre. P. 26. Lahore.

45. SHEIKH S (2009) Problems of Pakistani Women. Lecture delivered on 14 May, 2009 at Institute of Policy Studies: Islamabad.
46. SKALLI LH (2011) Constructing Arab female leadership lessons from the Moroccan media. Gender \& Society, 25(4), 473-495.

47. STEIN JC (1997) Internal capital markets and the competition for corporate resources. The Journal of Finance, 52(1), 111-133.

48. THOMAS G (2003) Ethnic map of Afghanistan (PDF). Center for Afghanistan Studies, University of Nebraska at Omaha.

49. UNDP (2005) Political and Legislative Participation of Women in Pakistan: Issue and Perspective. UNDP Report. Islamabad. Pakistan.

50. UNITED NATIONS RESEARCH INSTITUTE FOR SOCIAL DEVELOPMENT (UNRISD) (2005). Gender Equality: Striving for Justice in an Unequal World. France: UNRISD.

51. WELLE B, HEILMAN ME (2007) Formal and informal discrimination against women at work. Research in social issues in management: Managing social and ethical issues in organizations, 229-252.

52. WORLD BANK (2014) Annual Report 2014. worldbank.org/annualreport2014. 